\title{
ARCTIC SEABIRDS: DIVERSITY, POPULATIONS, TRENDS, AND CAUSES
}

\author{
ANTHONY J. GASTON \\ Wildlife Research Division, Environment Canada, National Wildlife Research Centre, \\ Ottawa K1A OH3, Canada. \\ E-mail: tony.gaston@ec.gc.ca
}

\begin{abstract}
Populations and trends of Arctic seabirds have been the subject of substantial research since the 1930s in Europe and Greenland and since the 1950s in North America. The marine waters of the Arctic support 44 species of seabirds comprising 20 genera. There are four endemic monotypic genera and an additional 25 species for which the bulk of the population is confined to Arctic and sub-Arctic regions. Most Arctic seabirds have large populations, with only two species comprising less than 100,000 individuals and many species numbering in the millions. Population trends for several widespread Arctic species have been negative in recent decades. Conversely, some sub-Arctic species are spreading northwards. Climate change with consequent changes in competition and predation, and intensifying development in the north, increasingly threaten Arctic seabirds. Changes in ice conditions are likely to have far-reaching and potentially irreversible results. Received 22 February 2011, accepted 26 May 2011.
\end{abstract}

Gaston, A. J. 2011. Arctic seabirds: Diversity, populations, trends, and causes. Pages 147-160 in R. T. Watson, T. J. Cade, M. Fuller, G. Hunt, and E. Potapov (Eds.). Gyrfalcons and Ptarmigan in a Changing World, Volume I. The Peregrine Fund, Boise, Idaho, USA. http://dx.doi.org/10.4080/ gpcw.2011.0201

Key words: Seabirds, diversity, population size, population trends, Arctic.

SEABIRDS HAVE PROVIDED A SOURCE OF FOOD for Arctic peoples throughout their history and most major seabird colonies within the range of the post-Pleistocene Inuit expansion are associated with archaeological sites that attest to significant harvest and storage of seabirds (Freuchen and Salmonsen 1958, Nelson 1983). Some Arctic communities are heavily dependent on seabird harvesting (e.g., Ivujivik, Quebec, Gaston et al. 1985; Siorapaluk, Greenland, Malaurie 1985). Early European explorations in Arctic and sub-Arctic waters also made extensive use of seabirds for food (e.g., Henry Hudson's crew, Prickett 1611). Consequently, these birds have been of interest to people for a very long time.
Census of Arctic seabird colonies began in the 1930s in Greenland (Salomonsen 1950) and Russia (Uspenski 1956), the 1950s in eastern Canadian Arctic (Tuck 1961), the 1960s in Spitzbergen (Norderhaug et al. 1977, Mehlum and Bakken 1994), and the 1970s in the northern Bering and Chukchi seas (www.seabirds. net/maps/dev/north-pacific.php?v=14). Subsequent monitoring was sporadic in most regions until the 1980s, but has become more regular since then (CAFF Seabird Working Group, unpubl.). However, many breeding sites are extremely remote, in places where navigation is challenging and support for aircraft very distant. Consequently, although we have a good picture of distributions, and some idea of pop- 
ulation sizes, our information on population trends is rather fragmentary and localised and our knowledge of causes behind change in populations is even less substantial (Gaston et al. 2009). This paper attempts to review what we do know of seabird population size and status, understanding that there is considerable uncertainty especially about population trends.

\section{SPECIES RICHNESS AND DISTRIBUTION}

Forty-four species of seabirds breed within the Arctic (Table 1), 23 in the High Arctic, 41 in the Low Arctic. They belong to 20 genera, the richest in species being Larus (10 spp.), Gavia (5 spp.) and Stercorarius (4 spp.). Six genera are monotypic. The majority are members of the order Charadriiformes, 34 species, including four endemic genera, all monotypic: Little Auk (Alle alle), Ivory Gull (Pagophila eburnea), Sabine's Gull (Xema sabini), and Ross's Gull (Rhodostethia rosea). Fifteen species are circumpolar in their distribution, occurring in Canada, Alaska and over most of the Russian Arctic. There are two 'bi-polar' genera, found at high latitudes in both hemispheres-the fulmars (Fulmarus), and the skuas and jaegers (Stercorarius), the former likely originating in the southern hemisphere (Voous 1949), the latter in the northern hemisphere (Furness 1987). All four species of Stercorarius found in the northern hemisphere are endemic to the Arctic and sub-Arctic, as is the single fulmarine petrel, all the loons, terns and auks and five species of Larus gulls.

Overall diversity is highest in the low-Arctic of the Pacific Basin (Chukchi and Bering seas and adjacent coasts) where 28 species occur in the Alaskan low-Arctic (including islands south to $60^{\circ} \mathrm{N}$ ) and 26 species on the Asian side. Other biodiversity hotspots occur in West Greenland (24 spp.), eastern Canadian Arctic (Nunavut, northern Quebec and Labrador, 22 spp.), and Iceland (22 spp. excluding the subArctic/boreal species found only on the south coast).
Several taxa have been elevated to species status only recently and were previously considered sub-species. These splits mainly involve distinguishing North American and Eurasian populations: Arctic/Pacific Loons (Gavia arctica/pacifica), American/European Herring Gull (Larus smithsonianus/argentatus). The large white-headed gulls of the genus Larus are divided into several poorly differentiated and mostly allopatric species in northern Asia and on the west coast of North America. Much of their diversity was regarded as infra-specific until recently (cf. Vaurie 1965, Olsen and Larsson 2003).

The distributions of many species of Arctic marine birds were poorly known until the latter half of the twentieth century. In addition, many species are long-lived and conservative in their breeding site adherence, making them slow to alter their breeding range. Consequently, we have few data on which to assess trends in range extent among Arctic seabirds. No strictly Arctic species has become extinct during historic times, although three sub-Arctic species, Spectacled Cormorant (Phalacrocorax perspicillatus) (Commander Islands), Labrador Duck (Camptorhynchus labradorius) (Labrador) and Great Auk (Pinguinus impennis) (Newfoundland and Iceland) were hunted to extinction by Europeans in the $19^{\text {th }}$ Century (Fuller 2000). Ivory Gull and Ross's Gull are listed by IUCN/Birdlife International as threatened or endangered at a world scale.

There is some evidence for the recent northward spread of predominantly temperate or low-Arctic species: Ancient Murrelet (Synthliboramphus antiquus) in the Bering Sea (Gaston and Shoji 2010), Horned Puffin (Fratercula corniculata) in the Beaufort Sea (Moline et al. 2008), Mew (Common) Gull (Larus canus) in Iceland (Petersen and Thorstensen 2004), Black-headed Gull (Chroicocephalus ridibundus) in Labrador (Chaulk et al. 2004), Great Black-backed Gull (Larus marinus) and Razorbill (Alca torda) in Hudson Bay (Gaston and Woo 2008). At the 
same time there is evidence of a retreat for at least one high-Arctic species, with the range of the Ivory Gull contracting in northern Nunavut, with most colonies on northern Baffin Island and eastern Devon Island deserted while numbers have remained stable farther north on central Ellesmere Island (Environment Canada 2010). Southern colonies are also decreasing in Greenland (Gilg et al. 2009). The population trend in Russia is unclear (Gilchrist et al. 2008) but some colonies at their western extremity in the Barents Sea region have been deserted (Gavrilo 2010). The population of Kittlitz's Murrelet (Brachyramphus brevirostris), a species associated with tidewater glaciers in the low- and sub-Arctic of the North Pacific, is declining in its core breeding range in south central Alaska and perhaps elsewhere (Kuletz et al. 2003, Stenhouse et al. 2008). Similar changes have been noted by local people:

\section{"I have started to notice birds which I used to only see on TV, little birds which have multi-coloured bills, that fly home with multiple cod in their beaks and that burrow into the soil. I think these are the Atlantic puffins [Fratercula arctica], which are located some distance south migrating north due to the disappear- ance of the ice cover during the summer months" (Pijamin: Elders Conference on Climate Change 2001).}

With little evidence for range changes, it is difficult to ascribe causes. The spread of Razorbill in Hudson Bay has been linked to an increase in sandlance Ammodytes spp., perhaps related to diminishing ice cover (Gaston and Woo 2008). Reduced ice cover also is likely to be involved in the arrival of Horned Puffin in the Beaufort Sea. The association of Kittlitz's Murrelet with tidewater glaciers makes it likely that recent declines are caused by the retreat of many Alaskan coastal glaciers (Stenhouse et al. 2008). In the longer run, changes in ice cover must affect the distribution of ice- associated species such as Ross's and Ivory gulls and Thick-billed Murre (Uria lomvia).

\section{Population Sizes and Densities}

Most species have populations numbering in the hundreds of thousands and only two are believed to number less than 100,000 breeding individuals: Ivory Gull and Thayer's Gull (Larus thayeri) (Table 1). Among high-Arctic specialists, the Ivory Gull has decreased precipitously in Canada (by $80 \%$ since the 1980 s), has decreased in Greenland, and shows range contraction in the northern Barents Sea. In all cases the southern parts of the range seem to be more affected than northern parts (Gilchrist and Mallory 2005, Gilchrist et al. 2005, Gilg et al. 2009, Environment Canada 2010). Of the other two exclusively high-Arctic species, population size for Thayer's Gull, which is confined to eastern and central parts of the Canadian high-Arctic and northwest Greenland, is very poorly known, but certainly numbers less than 100,000 (AJG, M.L. Mallory and H.G. Gilchrist unpubl.). The Little Auk, although well-distributed in small pockets around the Arctic Ocean, is numerically concentrated into a single location in northwest Greenland (Crimson Cliffs and adjacent coasts of Thule District) where the population, although difficult to count, is believed to greatly exceed ten million birds (Renaud et al. 1982). Censusing such an aggregation is almost impossible and no information is available on trends. Some small colonies in southern Greenland and in Iceland have disappeared since the 1930s (Nettleship and Evans 1985).

Thick-billed and Common Murres (Uria aalge)are among the most abundant seabirds in the Northern Hemisphere with both species exceeding 10 million adults (Gaston and Jones 1998). Both have circumpolar distributions. The more northern species, $U$. lomvia, occurs mostly in Arctic waters, where it constitutes a higher proportion of seabird biomass than any other species. Both species of murre have shown regional population changes over the 
Table 1. Seabird species occurring in the circumpolar Arctic, by region, with global population estimate (orders of magnitude and IUCN status).

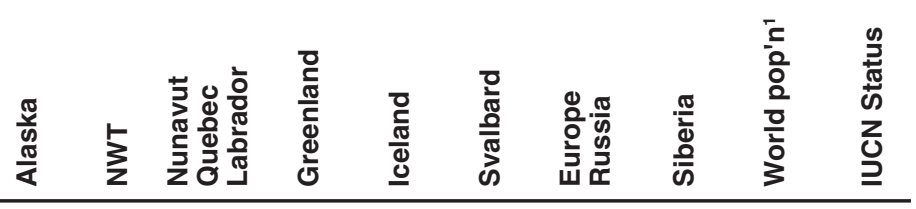

\begin{tabular}{|c|c|c|c|c|c|c|c|c|c|c|c|}
\hline Loons & Gaviidae & & & & & & & & & & \\
\hline Red-throated Loon & Gavia stellata & $x$ & $x$ & $x$ & $x$ & $x$ & $x$ & $x$ & $x$ & 6 & LC \\
\hline Black-throated Loon & Gavia arctica & $x$ & & & & & $x$ & $x$ & $x$ & 6 & LC \\
\hline Pacific Loon & Gavia pacifica & $x$ & $x$ & $x$ & & & & & $x$ & 6 & LC \\
\hline Great Northern Loon & Gavia immer & $x$ & $x$ & $x$ & $x$ & $x$ & & & & 6 & LC \\
\hline Yellow-billed Loon & Gavia adamsii & $x$ & $x$ & $x$ & $x$ & & & $x$ & $x$ & 5 & LC \\
\hline Petrels & Procellariidae & & & & & & & & & & \\
\hline Northern Fulmar & $\begin{array}{l}\text { Fulmarus } \\
\text { glacialis }\end{array}$ & $x$ & & $x$ & $x$ & $x$ & $x$ & $x$ & $x$ & 8 & LC \\
\hline Cormorants & Phalacrocoracidae & & & & & & & & & & \\
\hline Great Cormorant & $\begin{array}{l}\text { Phalacrocorax } \\
\text { carbo }\end{array}$ & & & & $x$ & $x$ & & & & 6 & LC \\
\hline European Shag & $\begin{array}{l}\text { Phalacrocorax } \\
\text { aristotelis }\end{array}$ & & & & & $x$ & & $x$ & & 6 & LC \\
\hline Pelagic Cormorant & $\begin{array}{l}\text { Phalacrocorax } \\
\text { pelagicus }\end{array}$ & $x$ & & & & & & & $x$ & 6 & LC \\
\hline Gannets & Sulidae & & & & & & & & & & \\
\hline Northern Gannet & Morus bassanus & & & & & $x$ & & $x$ & & 6 & LC \\
\hline Jaegers/Skuas & Stercorariidae & & & & & & & & & & \\
\hline Great Skua & Stercorarius skua & & & & & $x$ & $x$ & $x$ & & 5 & LC \\
\hline Pomarine Skua & $\begin{array}{l}\text { Stercorarius } \\
\text { pomarinus }\end{array}$ & $x$ & $x$ & X & $x$ & & & $x$ & $x$ & 6 & LC \\
\hline Parasitic Jaeger & $\begin{array}{l}\text { Stercorarius } \\
\text { parasiticus }\end{array}$ & $x$ & $x$ & $x$ & $x$ & $x$ & $x$ & $x$ & $x$ & 7 & LC \\
\hline Long-tailed Jaeger & $\begin{array}{l}\text { Stercorarius } \\
\text { longicaudus }\end{array}$ & $x$ & $x$ & $x$ & $x$ & & $x$ & $x$ & $x$ & 7 & LC \\
\hline
\end{tabular}


Table 1. (continued)

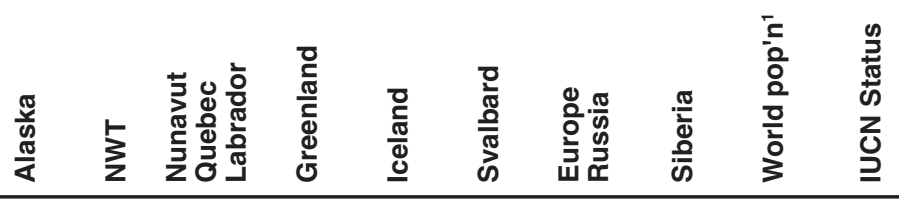

\section{Gulls and Terns Laridae}

Black-headed Gull Chroicocephalus

$\begin{array}{llll}\text { ridibundus } & X & 8 & \text { LC }\end{array}$

Mew Gull

Larus canus $\quad X \quad X$

G. Black-backed

Larus marinus

Gull

Glaucous Gull

Iceland Gull

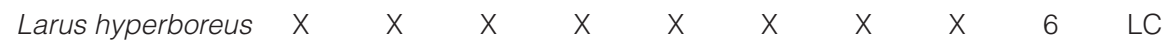

Thayer's Gull

Larus glaucoides

Amer. Herring Gull

Larus thayeri

$x \quad x$

LC

Larus

smithsonianus

Lesser Black-backed Larus fuscus

Gull

Herring Gull

Larus argentatus

Vega Gull

Larus vegae

Slaty-backed Gull

Ivory Gull

Ross's Gull

Sabine's Gull

Black-leg. Kittiwake

Arctic Tern

Larus schistisagus $\mathrm{X}$

Pagophila eburnea

Rhodostethia rosea

Xema sabini

Rissa tridactyla

Sterna paradisaea

Onychoprion

aleuticus

\section{Alcidae}

\section{Auks}

Little Auk

Common Murre

Alle alle

Thick-billed Murre

Razorbill

Uria aalge

Uria lomvia

Alca torda

Black Guillemot

Pigeon Guillemot

Kittlitz's Murrelet

Parakeet Auklet

Crested Auklet

Least Auklet

Atlantic Puffin

Horned Puffin

Tufted Puffin
Cepphus grylle $\quad \mathrm{X}$

Cepphus columba $\quad X$

Brachyrhamphus

brevirostris

Aethia psittacula

Aethia cristatella

Aethia pusilla

Fratercula arctica

Fratercula

corniculata

Fratercula cirrhata

$x$

$X$

X $x$
X

$X$

$X$

X

$x$

x $\quad x$

x

$x$

X

$x$

$x \quad x$

$x \quad x \quad x$

$x$

$x$

$x \quad x$

$x$
$x$
$x$
$x$

$x$

$\begin{array}{lll} & & 6 \\ x & x & 6 \\ x & & 7 \\ & x & 6 \\ & x & 6 \\ x & & 4 \\ & x & 5 \\ & x & 6 \\ x & x & 8 \\ x & x & 7\end{array}$

LC

LC

LC

LC

NT

LC

LC

LC

LC

5

LC

$\begin{array}{lll}x & x & x \\ x & x & x \\ x & x & x \\ x & x & x\end{array}$

$x$
$x$
$x$

$\begin{array}{ll}x & x \\ x & x \\ x & x \\ x & \\ x & x\end{array}$

LC

LC

LC

LC

LC

LC

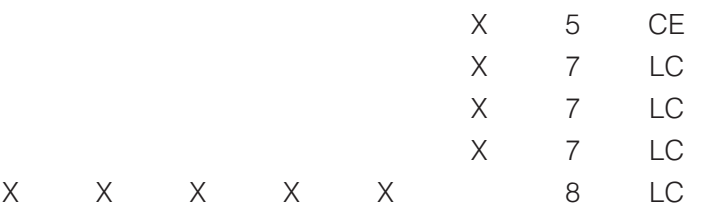

$\times \quad 7 \quad$ LC
$X$

$\begin{array}{lll} & 7\end{array}$

${ }^{1}$ (orders of magnitude, breeding individuals) 
past three decades, with trends in the North Pacific and Northwest Atlantic generally positive or stable when trends in the European Arctic were negative and vice versa (Irons et al. 2008). By combining population trend data from around the Arctic with information on sea surface temperature changes (SST) and decadal-scale climate-ocean oscillations, Irons et al. (2008) showed that population growth was most often positive where conditions remained relatively stable and negative when change, either colder or warmer, was large. This result suggests that not only the direction but the magnitude of change may be important in determining biological outcomes of climate. Trends in different regions switched direction with regime shifts. However, U. lomvia populations have declined in all regions except the Canadian eastern Arctic since the 1970s, whereas no single global trend can be identified for $U$. aalge.

The population of Thick-billed Murres in Central West Greenland is much depressed compared to numbers in the early nineteenth century, as a result of heavy harvesting of adults at colonies (Evans and Kampp 1991), as well as drownings in gill-net fisheries (Tull et al. 1972) and shows no sign of recovery, with the population south of Thule District remaining at $<20 \%$ of historical levels (Kampp et al. 1994, Merkel et al. 2007, F. Merkel pers. comm. 2010). Numbers in East Greenland, although small, have also declined. Similarly, numbers in Novaya Zemlya are considerably lower than in the early twentieth century when the population numbered several million birds. Currently, there are thought to be in the region of one million breeders (Bakken and Pokrovskaya 2000). In Spitzbergen, numbers of Thick-billed Murres were thought to be stable up to the 1990s, but have since decreased, especially in the southern part of the archipelago (CAFF Circumpolar Seabird Working Group, unpubl.)

In Iceland, numbers of Thick-billed Murres decreased at 7\% per year between 1983-1985 and 2005-2008, while numbers of Common Murres decreased abruptly between 19992005 after modest increases earlier (Gardarsson 2006). Northern Fulmar (Fulmarus glacialis), Black-legged Kittiwake (Rissa tridactyla) and Razorbill also decreased, although some small colonies increased (Gardarsson et al. 2009).

\section{Causes of Population Changes}

The causes of population and range changes can rarely be confidently attributed to a single source. The decline of Ivory Gulls in the Canadian Arctic illustrates a case where several potential contributory causes can be identified: heavy hunting of adults in Greenland (Stenhouse et al. 2004), high levels of mercury in eggs (Braune et al. 2006) and changes in ice conditions associated with global warming (Environment Canada 2010). All may have contributed to recent population decline. Only where population declines are abrupt and associated with strong environmental signals, can causes be confidently assigned. This was the case for Common Murre populations in the southern Barents Sea in 1985-87 when numbers fell by $80 \%$ in response to starvation following the collapse of the Barents Sea Capelin (Mallotus villosus) stock (Anker-Nilssen et al. 1997). The population subsequently recovered to near its former level (Krasnov et al. 2007). Similarly, an $80 \%$ decrease in Lesser Blackbacked Gulls in northern Norway coincided with a collapse in the stock of spring spawning Herring (Clupea harengus) (Bustnes et al. 2010).

Most changes in demography and population status of Arctic seabirds that have been linked with climate changes have, to date, been ascribed to causes operating through the food chain (Harris et al. 2005, Sandvik et al. 2005, Durant et al. 2004, 2006, Irons et al. 2008). However, a few cases where direct effects have occurred have been documented. Mallory et al. (2009) reported a wide range of weatherrelated mortalities at Arctic seabird colonies 
and suggested that some types of mortality, especially those associated with increases in extreme weather events, could create heavier mortality in the future. In northern Hudson Bay in the late 1990s, a combination of warm summer weather and earlier emergence by mosquitoes, leading to heavy blood-sucking, caused the death of some incubating Thickbilled Murres through a combination of dehydration and hyperthermia. In addition, some birds left their eggs unattended for periods of several hours, resulting in many losses to predatory gulls (Gaston et al. 2002). These effects had not been recorded previously in 20 years of observations. Changes in the timing of snow-cover and ice-melt affect the availability of breeding sites to crevice, scree and burrownesting species, such as puffins and Little Auks (Birkhead and Harris 1985). Such changes in accessibility can result in altered interactions with predators, as observed for Antarctic Petrels (Thalassoica antarctica) by van Franeker et al. (2001).

Although both species of murre are currently abundant, many populations have been declining for several decades (Johnsen et al. 2010). Problems facing murres include fisheries interactions, contaminants and oil spills and, in some parts of their range, hunting (especially of $U$. lomvia). For $U$. lomvia, changes in the extent and timing of sea-ice cover over the past several decades are leading to changes in phenology and reproduction with adverse consequences for nestling growth (Gaston et al. 2005). These changes seem likely to intensify. Levels of some contaminants, especially mercury, have increased in murre eggs in the North American Arctic since the 1970s, although they remain at sublethal levels (Braune et al. 2001). If climate change leads to increased shipping and oil and gas exploitation in Arctic waters, the increased risk of spills would also pose a potential hazard for murres, which are extremely susceptible to mortality from oil pollution (Wiese and Robertson 2004). In the long-term, range contraction of $U$. lomvia in response to the retreat of Arctic sea ice appears likely. Eventually it may be replaced by $U$. aalge and other more southern auks.

Substantial research has been carried out in the Barents Sea region and in the Canadian Arctic on concentrations and trends in contaminants, especially organohaline compounds and heavy metals (Braune et al. 2001, Letcher et al. 2010). Very high levels of mercury (Braune et al. 2006) and organohaline compounds (Miljeteig et al. 2009) have been found in the eggs of Ivory Gulls from Canada and Svalbard and high organohaline concentrations occur also in Glaucous Gulls (Larus hyperboreus) from Svalbard (Bustnes et al. 2003, 2004), perhaps causing mortality in some cases (Gabrielsen et al. 1995, Sagerup et al. 2009). These species scavenge marine mammal carcasses, putting them high up the food chain and hence subject to high biomagnification effects. They may also frequent garbage dumps around human population centres. Levels of contaminants in other species generally do not approach those likely to impact populations (Gabrielsen 2007, Letcher et al. 2010), except in the case of point-source pollution resulting from industrial sites (e.g., Kuzyk et al. 2003).

Changes in the timing of seasonal events for high-latitude marine birds have been identified for many southern hemisphere species (Croxall et al. 2002, Rolland et al. 2010), as well as some Arctic seabird populations (Gaston et al. 2005, Byrd et al. 2008a,b, Moe et al. 2009). For some Arctic species, reproductive success is inversely correlated with date of laying, e.g., Little Auks (Moe at al. 2009), but this relationship may vary among geographical areas; it is true for Thick-billed Murres breeding at Prince Leopold Island, Nunavut, but not for the same species breeding in northern Hudson Bay (Gaston et al. 2005). The importance of timing of breeding in determining the dynamics of Arctic seabird populations is supported by a correlation found between colony size and the timing of sea ice withdrawal in adjacent waters for Thick-billed Murres in Greenland (Laidre et al. 2008). 
Mismatching of breeding initiation with the seasonal peak of food availability may be a common phenomenon among seabirds confronted with rapidly changing seasonal timing (Bertram 2001, Wilhelm et al. 2008, Watanuki et al. 2009). It has been identified as a likely cause of reduced nestling growth for Thickbilled Murres in northern Hudson Bay (Gaston et al. 2009), as well as accounting for some of the variation in reproductive success of Black-legged Kittiwakes and Common Murres in sub-Arctic Alaska (Suryan et al. 2006, Schultz et al. 2009) and Newfoundland (Wilhelm et al. 2008).

Changes in seabird diets, both from year to year and over decades, have been reported from many sites. Diet switching is likely a fairly routine aspect of seabird biology (e.g., Montevecchi and Myers 1995, 1997, Barrett 2002). At Coats Island, northern Hudson Bay, Thick-billed Murres switched from feeding their chicks predominantly the ice-associated Arctic Cod (Boreogadus saida) to the more sub-Arctic Capelin in the mid-1990s (Gaston et al. 2003). The change was associated with an advance in the date of sea-ice clearance in the region.

Not all prey are equally suitable, especially for rearing nestling birds, and some prey switches can result in reduced productivity among seabirds (Litzow et al. 2002, Wanless et al. 2005, Gremillet et al. 2008). In the southwest Barents Sea in recent decades Herring has come to dominate over Capelin as a forage fish. This change has coincided with a decline in numbers of breeding Back-legged Kittiwakes ( $-8 \%$ per year after 1995$)$. Apparently Herring is not as satisfactory as Capelin as food for kittiwakes (Barrett 2007). At the Pribilof Islands, Sinclair et al. (2008) also observed a reduction in the proportion of Capelin in Black-legged Kittiwake and Thickbilled Murre diets between the 1980s and 2000s, while changes in the zooplankton diet of Least Auklets (Aethia pusilla) was also observed over the same period (Springer et al.
2007, Sheffield Guy 2009). These changes were associated with a warming of the adjacent surface waters and a retreat of winter sea ice. Similarly, in Iceland, the diet of most seabirds switched from sandlance to other fishes in the 2000s (Gardarsson 2006), a change also observed in boreal waters of the North Sea (Wanless et al. 2005). This diet change was contemporary with declines in most seabird populations.

Many seabirds are very conservative in their breeding sites, returning faithfully to large colonies that, in some cases, have been in existence for millennia (Gaston and Donaldson 1996). If climate change alters environmental conditions around such colonies it is unlikely that a mass exodus will take place in search of new colony locations. There are examples of large colonies suffering repeated reproductive failure over many years without any substantial emigration (e.g., Atlantic Puffins at Rost, Norway reared few chicks between 19691982, Anker-Nilssen and Rostad 1993). However, parasites and predators may be more mobile in response to climate change and may initiate or expand their activities at new sites. Some examples of such expansions have already been observed, with an increase in the incidence of tapeworms in alcids in Labrador and Greenland since the 1960s (Bin Muzaffar 2009) and the appearance of the parasitic tick (Ixodes uriae) on murres in Svalbard after 2000 (Coulson et al. 2009). The implications of these parasite range expansions are not yet clear but adverse consequences for the seabird populations involved are possible.

Currently Golden Eagles (Aquila chrysaetos) and White-tailed Sea-eagles (Haliaeetus albicilla), both of which cause disruption to nesting seabirds, only reach the fringes of the Arctic. Their northward spread could create problems for gulls, murres and other opennesting seabirds. Increasing predation of birds and their nests by Polar Bears (Ursus marinus) has also been observed, probably as a result of the bears coming ashore earlier in the season 
(Rockwell and Gormezano 2009, Smith et al. 2010). This could affect especially accessible species such as Little Auks (Stempniewicz 2007). Because of the potential for alternative prey, it is extremely difficult to predict how seabird populations will respond to changes in predator distributions.

\section{Conclusions}

The Arctic is an important area for marine bird diversity and endemism. Most Arctic seabird populations for which information is available over several decades have shown negative trends in recent years. These trends are superimposed on a situation where several important populations were substantially depressed by anthropogenic mortality, compared with numbers in the first half of the twentieth century (especially Thick-billed Murres in Greenland and Novaya Zemlya).

Only a few instances are available where recent trends can be traced to particular causes but stressors include fisheries activities, pollution, and climate change. The last, especially as manifested in changes in the timing of the open water season, is affecting the timing of seasonal events in marine ecosystems and this is affecting the optimal timing of breeding, especially in low-Arctic areas. Changes in ice conditions, especially, are likely to have farreaching and potentially irreversible consequences. These changes are also encouraging the northward expansion of sub-Arctic species, although such changes in range are relatively small, as yet. Changes in the distributions of predators and parasites have also been noted and these may have important consequences for Arctic seabirds. Because of the number of Arctic endemic seabird taxa, the decline of Arctic marine birds presages a significant loss of global biodiversity.

\section{ACKNOWLEDGMENTS}

Thanks to the many students, contractors, collaborators and volunteers who have assisted with seabird research and monitoring in the Canadian Arctic. Our efforts would not have been successful without the financial and logistic support of Natural Resources Canada (Polar Continental Shelf Program), the Nunavut Research Institute, Indian and Northern Affairs Canada (Northern Contaminants Program), and various branches of Environment Canada (Canadian Wildlife Service and Science and Technology Branch). For information and advice on literature sources, I thank Carsten Egevang, Maria Gavrilov, Arnthor Gardarsson, Grant Gilchrist, David Irons, Mark Mallory, Freydig Vigfúsdóttir, and members of the C-bird working group of CAFF.

\section{Literature Cited}

Anker-Nilssen, T., AND O. D. Rostad. 1993. Census and monitoring of puffins Fratercula arctica on Rost, North Norway, 19791988. Ornis Scandinavica 24:1-9.

ANKER-NilsSEN, T., R. T. BARRETt, AND J. V. KRASNOV. 1997. Long- and short-term responses of seabirds in the Norwegian and Barents Seas to changes in stocks of prey fish. Forage Fishes in Marine EcosystemsLowell Wakefield Fisheries Symposium Series, no. 14:683-698.

Bakken, V., and I. V. Pokrovskaya. 2000. Thick-billed Murre. Pages 119-124 in T. Anker-Nilssen, V. Bakken, H. Strøm, A.N. Golovkin, V.V. Bianki, and I.P. Tatarinkova (Eds.). The Status of Marine Birds Breeding in the Barents Sea Region. Norsk Polarinstitutt, Troms $\varnothing$, Norway.

BARrett, R. T. 2002. Atlantic Puffin Fratercula arctica and Common Guillemot Uria aalge chick diet and growth as indicators of fish stocks in the Barents Sea. Marine Ecology Progress Series 230:275-287.

BARRETT, R. T. 2007. Food web interactions in the southwestern Barents Sea: Black- 
legged Kittiwakes Rissa tridactyla respond negatively to an increase in Herring Clupea harengus. Marine Ecology Progress Series 349:269-276.

Bertram, D. F., D. L. Mackas, and S. M. MCKINNELL. 2001. The seasonal cycle revisited: Interannual variation and ecosystem consequences. Progress in Oceanography 49:283-307.

Bin Muzaffar, S. 2009. Helminths of murres (Alcidae: Uria spp.): Markers of ecological change in the marine environment. Journal of Wildlife Diseases 45:672-683.

BirkHEAD, T. R., AND M. P. HARRIS. 1985. Ecological adaptations for breeding in the Atlantic Alcidae. Pages 205-261 in D. N. Nettleship and T. R. Birkhead (Eds.). The Atlantic Alcidae. Academic Press, London, UK.

Braune, B. M., G. M. Donaldson, and K. A. Hobson. 2001. Contaminant residues in seabird eggs from the Canadian Arctic. Part I. Temporal trends 1975-1998. Environmental Pollution 114:39-54.

Braune B. M., M. L. Mallory, and H. G. GILCHRIST. 2006. Elevated mercury levels in a declining population of Ivory Gulls in the Canadian Arctic. Marine Pollution Bulletin 52:978-982.

Bustnes, J. O., T. ANKER-NilsSEN, AND S. H. LORENTSEN. 2010. Local and large-scale climatic variables as predictors of the breeding numbers of endangered Lesser Black-backed Gulls on the Norwegian Coast. Journal of Ornithology 151:19-26.

Bustnes, J. O., K. E. ERikstad, J. U. SkaAre, V. BAKKEN, AND F. MEHLUM. 2003. Ecological effects of organochlorine pollutants in the Arctic: A study of the Glaucous Gull. Ecological Applications 13:504-15.

Bustnes, J. O., S. A. Hanssen, I. Folstad, K. E. ERikstad, D. Hasselquist, and J. U. SKAARE. 2004. Immune function and organochlorine pollutants in arctic breeding Glaucous Gull. Archives of Environmental Contamination and Toxicology 47:530-41.

Byrd, G. V., J. A. SCHMUTZ, AND H. M. RENNER. 2008a. Contrasting population trends of piscivorous seabirds in the Pribilof Islands: A 30-year perspective. Deep Sea Research Part II-Topical Studies in Oceanography 55:1846-1855.

Byrd, G. V., W. J. Sydeman, H. M. RenNer, AND S. MinOBE. 2008b. Responses of piscivorous seabirds at the Pribilof Islands to ocean climate. Deep Sea Research Part IITopical Studies in Oceanography 55:18561867.

CAFF Circumpolar Seabird Group. 1996. Murre conservation in the circumpolar Arctic. Poster published by Committee on Arctic Flora and Fauna, Environment Canada, Canada.

Chaulk, K. G., J. G. Robertson, and W. A. MonteVeCCHI. 2004. Breeding range update for three seabird species in Labrador. Northeastern Naturalist 11:479485.

Coulson, S. J., E. LorentZen, H. STROM, AND G. W. Gabrielsen. 2009. The parasitic tick Ixodes uriae (Acari: Ixodidae) on seabirds from Spitsbergen, Svalbard. Polar Research 28:399-402.

Croxall, J. P., P. N. Trathan, and E. J. MurPHY. 2002. Environmental Change and Antarctic Seabird Populations. Science 297:1510-1514.

Durant, J. M., T. Anker-Nilsson, D. O. Huermann, AND N. C. Stenseth. 2004. Regime shifts in the breeding of an Atlantic Puffin population. Ecology Letters 7:388394.

Durant, J. M., T. ANKer-Nilsson, AND N. C. STENSETH. 2006. Ocean climate prior to breeding affects the duration of the nestling period in the Atlantic Puffin. Biology Letters 2: 628-631.

Elders Conference on Climate Change. 2001. Cambridge Bay, Nunavut. Nunavut Tunngavic Inc., Iqaluit, Canada.

EnVIRONMENT CANADA. 2010. Recovery Strategy for the Ivory Gull (Pagophila eburnea) in Canada [Draft]. Species at Risk Act Recovery Strategy Series. Environment Canada, Ottawa, Canada. 
Evans, P. G. H., AND K. KAMPP. 1991. Recent changes in Thick-billed Murre populations in West Greenland. Canadian Wildlife Service Occasional Paper 69:7-14.

Freuchen, P., And F. Salmonsen. 1958. The Arctic Year. G. P. Putnam, New York, USA.

Fuller, E. 2000. Extinct Birds. Oxford University Press, Oxford, UK.

FurNess, R. W. 1987. The Skuas. T. and A. D. Poyser, Calton, UK.

Gabrielsen, G. W. 2007. Levels and effects of persistent organic pollutants in arctic animals. Pages 377-412 in J. B. Orbaek, R. Kallenborn, I. Tombre, E. N. Hegseth, S. Falk-Petersen, and A. H. Hoel (Eds.). Arctic-Alpine Ecosystems and People in a Changing Environment. Springer Verlag, Berlin, Germany.

Gabrielsen, G. W., J. U. Skatre, A. Polder, AND V. BAKKEN. 1995. Chlorinated hydrocarbons in Glaucous Gulls (Larus hyperboreus) in the southern part of Svalbard. Science of the Total Environment 160/161:337-346.

GARDARSSON, A. 2006. Nýlegar breytingar á fjölda íslenskra bjargfugla [Recent changes in cliff-breeding seabirds in Iceland]. Bliki 27:13-22.

Gardarsson, A., G. A. Gudmundsson, K. LILLIENDAHL, AND F. VIGFÚSDÓTTIR. 2009. Status of cliff-breeding seabirds in Iceland in 2005-08. Poster for Seabird group Conference, March 2009, Brugge, Belgium.

GASTON, A. J., AND G. DonAlDSON. 1996. Peat deposits and Thick-billed Murre colonies in Hudson Strait and northern Hudson Bay: Clues to post glacial colonization of the area by seabirds. Arctic. 48:354-358.

Gaston, A. J., And I. L. Jones. 1998. The Auks - Alcidae. Oxford University Press, Oxford, UK.

Gaston, A. J., And A. Shout. 2010. The Ancient Murrelet Synthliboramphus antiquus. In A. Poole and F. Gill (Eds.). The Birds of North America, no. 132 [revised] Academy of Natural Sciences, Philadelphia, and American Ornithologists' Union, Washington, DC, USA.
Gaston, A. J., AND K. Woo. 2008. Razorbills Alca torda follow subarctic prey into the Canadian Arctic: Colonization results from climate change? Auk 125:939-942.

Gaston, A. J., D. F. Bertram, A. W. Boyne, J. W. Chardine, G. Davoren, A.W. DiaMOND, A. Hedd, W. A. MonteVeCChi, J. M. HipfNER, M. J. F. LEMON, M. L. MALLORY, J-F. RAil, AND G. J. Robertson. 2009. Changes in Canadian seabird populations and ecology since 1970 in relation to changes in oceanography and food webs. Environmental Reviews 17:267-286.

Gaston, A. J., D. K. Cairns, R. D. Elliot, AND D. G. NoBle. 1985. A natural history of Digges Sound. Canadian Wildlife Service Report Series No. 46:1-63.

Gaston, A. J., H. G. Gilchrist, and J. M. HIPFNER. 2005. Climate change, ice conditions and reproduction in an Arctic nesting marine bird: The Thick-billed Murre (Uria lomvia, L.). Journal of Animal Ecology 74:832-841.

Gaston, A. J., J. M. Hipfner, And D. CAMPBELL. 2002. Heat and mosquitoes cause breeding failures and adult mortality in an Arctic-nesting seabird. Ibis 144:185-191.

Gaston, A. J., K. Woo, And J. M. Hipfner. 2003. Trends in forage fish populations in northern Hudson Bay since 1981, as determined from the diet of nestling Thickbilled Murres Uria lomvia. Arctic 56:227-233.

GAVRILO, M. V. 2010. Increasing importance of Siberian shelf seas for polar marine top predators under conditions of the modern warming Arctic. Presentation at Oslo Science Conference, 2010, Oslo, Norway.

Gilchrist, H. G., AND M. L. MALlORY. 2005. Declines in the abundance and distribution of the Ivory Gull (Pagophila ebernea) breeding in Arctic Canada. Biological Conservation 121:303-309.

Gilchrist, H. G., M. L. Mallory, and F. MERKEL. 2005. Can local ecological knowledge contribute to wildlife management? Case studies of migratory birds. Ecology and Society 10(1):20. [Online.] 
Available at http://www.ecologyandsociety .org/vol10/iss1/art20/

Gilchrist, H. G., H. Strom, M. V. Gavrilo, AND A. MosBeCH. 2008. International ivory gull conservation strategy and action plan. CAFF International Secretariat, Circumpolar Seabird Group, CAFF Technical Report no. 18.

Gilg, O., D. Boertmann, F. Merkel, A. AEBISCHER, AND B. SABARD. 2009. Status of the endangered Ivory Gull, Pagophila eburnea, in Greenland. Polar Biology 32:1275-1286.

Gremillet, D., L. Pichegru, G. Kuntz, A. G. WoAKes, S. Wilkinson, R. J. M. CRAWFORD, AND P. G. RYAN. 2008. A junk-food hypothesis for gannets feeding on fishery waste. Proceedings of the Royal Society B 275:1149-1156.

Harris, M. P., T. ANKER-Nilssen, R. H. MCCleERY, K. E. ERIKSTAD, D. N. ShaW, AND V. GROSBOIS. 2005. Effect of wintering area and climate on the survival of adult Atlantic Puffins Fratercula arctica in the eastern Atlantic. Marine Ecology Progress Series 297:283-296.

Irons, D. B., T. ANKER-NILSSEN, A .J. GASTON, G. V. Byrd, K. FALK, H. G. GILChrist, M. Hario, M. HJernquist, Y. V. Krasnov, A. Mosbech, B. Olsen, A. Petersen, J. Reid, G. J. Robertson, H. Strom, and K. D. WoHL. 2008. Magnitude of climate shift determines direction of circumpolar seabird population trends. Global Change Biology 14:1455-1463.

Johnsen, K. I., B. Alfthan, L. Hislop, AND J. F. SKAAlVIK (Eds.). 2010. Protecting Arctic Biodiversity. United Nations Environment Programme, GRID-Arendal, Norway.

Kampr, K., D. N. Nettleship, and P. G. H. Evans. 1994. Thick-billed Murres of Greenland: Status and prospects. Pages 133-154 in D. N. Nettleship, J. Burger, and M. Gochfeld (Eds.). Seabirds on Islands: Threats, Case Studies, and Action Plans. Birdlife International, Cambridge, UK.

Krasnov, Y. V., R. T. Barrett, AND N. G. Nikolaeva. 2007. Status of Black-legged
Kittiwakes (Rissa tridactyla), Common Guillemots (Uria aalge) and Brunnich's Guillemots (U-lomvia) in Murman, northwest Russia, and Varanger, north-east Norway. Polar Research 26:113-117.

KuletZ, K. J., S. W. Stephensen, D. B. Irons, E. A. LABRUNSKI, AND K. M. BRENNEMAN. 2003. Changes in the distribution and abundance of Kittlitz's Murrelets Brachyramphus brevirostris relative to glacial recession in Prince William Sound, Alaska. Marine Ornithology 31:133-140.

KuZYK, Z. Z. A., N. M. Burgess, J. P. Stow, AND G. A. Fox. 2003. Biological effects of marine PCB contamination on Black Guillemot nestlings at Saglek, Labrador: Liver biomarkers. Ecotoxicology 12:183197.

LAidRe, K. L., M. P. Heide-JøRgenSEn, J. NyeLAND, A. Mosbech, AND D. BoERTMANN. 2008. Latitudinal gradients in sea ice and primary production determine Arctic seabird colony size in Greenland. Proceedings of the Royal Society B 275:26952702.

Letcher, R. J., J. O. Bustnes, R. Dietz, B. M. Jenssen, E. H. Jørgensen, C. Sonne, J. Verreault, M. M. ViJayan, and G. W. GABRIELSEN. 2010. Exposure and effects assessment of persistent organohalogen contaminants in Arctic wildlife and fish. Science of the Total Environment 408:2995-3043.

Litzow, M. A., J. F. Piatt, A. K. Prichard, AND D. D. RoBy. 2002. Response of Pigeon Guillemots to variable abundance of highlipid and low-lipid prey. Oecologia 132:286-295.

Malaurie, J. 1985. The Last Kings of Thule. University of Chicago Press, Chicago, USA.

Mallory, M. L., A. J. Gaston, And H. G. GILChrist. 2009. Sources of breeding season mortality in Canadian Arctic seabirds. Arctic 62:333-341.

Mehlum, F., ANd V. BaKken. 1994. Seabirds in Svalbard (Norway): Status, recent changes and management. Pages 155-171 
in D. N. Nettleship, J. Burger, and M. Gochfeld (Eds.). Seabirds on Islands: Threats, Case Studies and Action Plans. Birdlife International, Cambridge, UK.

Merkel F. R., A. L. LABANSEN, AND L. WitTING. 2007. Monitering af lomvier og rider i Qaanaaq Kommune. 2006. Technical Report no. 69, Greenland Institute of Natural Resources, Pinngortitaleriffik.

Miljeteig, C., H. Strom, M. V. Gavrilo, A. Volkov, B. M. JENSSEN, AND G. W. GABRIELSEN. 2009. High levels of contaminants in Ivory Gull Pagophila eburnea eggs from the Russian and Norwegian Arctic. Environmental Science and Technology 43:5521-5528.

Moe, B., L. Stempniewicz, D. Jakubas, F. Angelier, O. Chastel, F. Dinessen, G. W. Gabrielsen, F. HansSen, N. J. KARnOvsky, B. RønNing, J. Welcker, K. WoJCZULANIS-JAKUBAS, AND C. BECH. 2009. Climate change and phenological responses of two seabird species breeding in the high-Arctic. Marine Ecology Progress Series 393:235-246.

Moline, M. A., N. J. Karnovsky, Z. Brown, G. J. Divoky, T. K. Frazer, C. A. Jacoby, J. J. TORRES, AND W. R. FRASER. 2008. High latitude changes in ice dynamics and their impact on polar marine ecosystems. Annals of the New York Academy of Sciences 1134:267-319.

Montevecchi, W. A., AND R .A. Myers. 1995. Prey harvests of seabirds reflect pelagic fish and squid abundance on multiple spatial and temporal scales. Marine Ecology Progress Series 117:1-9.

Montevecchi, W. A., AND R. A. Myers. 1997. Centurial and decadal oceanographic influences on changes in gannet populations and diets in the north-west Atlantic: Implications for climate change. ICES Journal of Marine Science 54:608-614.

Nelson, E. W. 1983. The Eskimo about Bering Strait. Smithsonian Institution Press, Washington, DC, USA.

NetTleship, D. N., AND P. G. H. Evans. 1985. Distribution and status of the Atlantic Alci- dae. Pages 55-154 in D. N. Nettleship, and T. R. Birkhead (Eds.). The Atlantic Alcidae. Academic Press, London.

Norderhaug, M., E. Brun, and G. U. MøLlen. 1977. Seabird Resources of the Barents Sea. Norsk Polarinstitutt Meddelelser 104. Norsk Polarinstitutt, Oslo, Norway.

OlsEn, K. M., AND H. LARSSON. 2003. Gulls of Europe, Asia and North America. Christopher Helm, London, UK.

Petersen, A., And S. Thorstensen. 2004. Vöktun stormmamfssofnsins i Eyjafirdi 1980-2000. Natturufraedingurinn 72:144154.

PRICKETT, H. 1611. Description of Digges Island. Pages 98-135 in G. M. Asher (Ed.). Henry Hudson the Navigator. The Hakluyt Society, London, 1860.

Renaud, W. E., P. L. Mclaren, and S. R. JoHnson. 1982. The Dovekie Alle alle as a spring migrant in Lancaster Sound and western Baffin Bay. Arctic 35:118-125.

RoCKWELl, R. F., AND I. J. GoRMEZANO. 2009. The early bear gets the goose: climate change, Polar Bears and Lesser Snow Geese in western Hudson Bay. Polar Biology 32:539-547

ROLlAND, V., H. WEIMERSKIRCH, AND C. BARBRAUD. 2010. Relative influence of fisheries and climate on the demography of four albatross species. Global Change Biology 16:1910-1922.

Sagerup, K., L. B. Helgason, A. Polder, H. StrøM, T. D. Josefsen, J. U. SkÅRE, AND G. W. GABRIELSEN. 2009. Persistent organic pollutants and mercury in dead and dying Glaucous Gulls (Larus hyperboreus) at Bjørnøya (Svalbard). Science of the Total Environment 407:6009-6016.

SAlomonsen, F. 1950. Grønlands Fugle. Munkssgaard, Copenhagen, Denmark.

SANDVIK, H., K. E. ERIKSTAD, R. T. BARRETT, AND N. G. YocCOZ. 2005. The effect of climate on adult survival in five species of North Atlantic seabirds. Journal of Animal Ecology 74:817-831. 
Schultz, M. T., J. F. Piatt, A. M. A. Harding, A. B. Kettle, and T. I. Van Pelt. 2009. Timing of breeding and reproductive performance in murres and kittiwakes reflect mismatched seasonal prey dynamics Marine Ecology Progress Series 393:249260.

Sheffield Guy, L. M., D. D. Roby, A. E. Gall, D. B. Irons, AND I. C. Rose. 2009. The influence of diet and ocean conditions on productivity of auklets on St. Lawrence Island, Alaska. Marine Ornithology 37:227-236.

Sinclair, E. H., L. S. Vlietstra, D. S. JohnSON, T. K. ZePPELIN, G. V. Byrd, A. M. SPRINGER, R. R. REAM, AND G. L. Hunt, JR. 2008. Deep Sea Research Part II-Topical Studies in Oceanography 55:1897-1918.

Smith, P. A., K. H. Elliott, A. J. Gaston, AND H. G. GILChrist. 2010. Early ice clearance leads to increased predation on breeding birds by Polar Bears. Polar Biology 33:1149-1153.

SPRINGER, A. M., G. V. B Yrd, AND S. J. IVERSON. 2007. Hot oceanography: Planktivorous seabirds reveal ecosystem responses to warming of the Bering Sea. Marine Ecology Progress Series 352:289-297.

STEMPNIEWICZ, L. 2007. The Polar Bear Ursus maritimus feeding in a seabird colony in Frans Josef Land. Polar Biology 12:33-36.

Stenhouse, I. J., G. J. Robertson, AND H. G. GILCHRIST. 2004. Recoveries and survival rate of Ivory Gulls banded in Nunavut. Waterbirds 27:486-492.

Stenhouse, I. J., S. Studebaker, And D. ZWIEFELHOFER. 2008. Kittlitz's Murrelet Brachyramphus brevirostris in the Kodiak Archepelago, Alaska. Marine Ornithology 36:59-66.

Suryan, R. M., D. B. Irons, E. D. Brown, P. G. R. Jodice, ANd D. D. Roby. 2006. Sitespecific effects on productivity of an upper trophic-level marine predator: Bottom-up, top-down, and mismatch effects on reproduction in a colonial seabird. Progress in Oceanography 68:303-328.
Tuck, L. M. 1961. The Murres. Canadian Wildlife Service, Ottawa, Canada.

Tull, C. E., A. W. May, and P. Germain. 1972. Mortality of Thick-billed Murres in West Greenland salmon fishery. Nature 237:42-44.

UsPensKI, S. M. 1956. "The bird bazaars of Novaya Zemlya." Canadian Wildlife Service Translations of Russian Game Reports, vol. 4, Ottawa, Canada.

Van Franeker, J. A., J. C. S. Creunels, W. VAN der Veer, S. Cleland, and G. ROBERTSON. 2001. Unexpected effects of climate change on the predation of Antarctic Petrels. Antarctic Science 13:430-439.

VAurIe, C. 1965. The Birds of the Palearctic Fauna-non-Passeriformes. H. F. and G. Witherby, London, UK.

Voous, K. H. 1949. The morphological, anatomical and distributional relationships of the Arctic and Antarctic fulmars (Aves, Procellariidae). Ardea 37:113-122.

WANLESS, S., M. P. HARRIS, P. REDMAN, AND J. R. SPEAKMAN. 2005. Low energy values of fish as a probable cause of a major seabird breeding failure in the North Sea. Marine Ecology Progress Series 294:1-8.

Watanuki, Y., M. Ito, T. Deguchi, and S. MinobE. 2009. Climate-forced seasonal mismatch between the hatching of Rhinoceros Auklets and the availability of anchovy. Marine Ecology Progress Series 393:259-271.

WIESE, F., AND G. J. ROBERTSON. 2004. Assessing seabird mortality from chronic oil discharges at sea. Journal of Wildlife Management 68:627-638.

Wilhelm, S. I., C. J. Walsh, AND A. E. STOREY. 2008. Time budgets of Common Murres vary in relation to changes in inshore Capelin availability. Condor 110:316-324. 